\title{
Medical Condition
}

National Cancer Institute

\section{Source}

National Cancer Institute. Medical Condition. NCI Thesaurus. Code C156809.

Any kind of illness or circumstance which requires medical monitoring. 